.Research Article

\title{
The Press Sectarian Crisis And Violence Against Women İn Plateau State Nigeria A Critical Evaluation
}

\author{
Justine John Dyikuk ${ }^{\mathrm{a} 1}$ \\ Lecturer, Department Of Mass Communication, Faculty Of Arts, University Of Jos, Nigeria \\ Justinejohndyikuk@Gmail.Com \\ Tahna'an Rosemary Moven ${ }^{\text {a2 }}$ \\ Lecturer, Department Of Mass Communication, Faculty Of Arts, University Of Jos, Nigeria \\ Rosetahnaan@Gmail.Com \\ Blessing Arsun Dapoet ${ }^{\mathrm{a} 3}$ \\ Lecturer, Department Of Mass Communication, Faculty Of Arts, University Of Jos, Nigeria \\ Blessingdapoet@Gmail.Com
}

\begin{abstract}
:
In most societies, women and girls are victims of war and violence. More often than not, during sectarian crises or escalating hostilities, they are sexually abused and left to suffer the brunt. With the aid of Human Rights Consciousness Journalism Theoretical Framework, this qualitative study "The Press, Sectarian Crisis and Violence against Women on the Plateau: A Critical Evaluation" investigated the matter in Plateau State, Nigeria. It found that ethnic and religious bias, lack of objective reportage and failure of international media are likely responsible for the failure of the press to bring an end to the orgy of violence against women in the state. The study recommended recruiting more women journalists, thorough reportage of women-related issues and proactive measures by female-journalists as possible panacea to the lingering cases of violence against women in Plateau. It concluded that given their rightful place in the media industry, women could reduce the menacing effects of gender-based violence. That way, the press would be exonerated from complicity in reporting women-in-conflict in Plateau State, Nigeria and beyond.
\end{abstract}

Keywords: Plateau, Press, Jos, Violence, Women.

\section{Introduction:}

Nigeria, being Africa's most populous country has been rocked by bouts of ethnic, religious, political and communal violence since 1999 (The New Humanitarian, 2004) when the state returned to democratic rule. Of these crises, gender-based based violence has been largely undocumented or unreported. Violence against women is one of the prevalent human rights violations. Research by WHO has revealed that violence against women is much underreported. It is estimated that 1 in 3 women around the world experience different forms of violence, like been raped, beaten or abused, which occurs across cultures and societies making it the most widespread, but among the least reported human rights abuses (WHO, 2018). It is prevalent during times of peace and stability, but risks escalate when a crisis strikes. In conflicts, women's bodies too often become battlefields, with violence used to humiliate and oppress. Risk is often amplified because women can be uprooted from their homes and separated from their usual support networks, while social and legal protection systems are weakened or destroyed (WHO, 2018). Nigeria Security Tracker (NST) data opine that violence has almost doubled since 2017. 2,037 deaths have been documented through all of 2018 in comparison to 1041 sectarian related deaths in 2017. NST identifies sectarian conflicts as acts of 
violence that occur between distinct identities based on groups (or as such in the Nigerian press). Plateau State has experienced series of crisis which have brought about destruction of lives and properties. Presenting the first official death toll of the Jos crisis, The New Humanitarian (2004) reported that more than 53,000 people were killed during three years of sectarian violence that engulfed Plateau State, central Nigeria, according to a report by The Committee of Rehabilitation and Reconciliation of Internally Displaced People. Most significantly, the conflicts that have brought about human right violationsperpetrated against the populace, especially women and children who apparently make up the most vulnerable group. Violence against women and girls is one of the most widespread, persistent and devastating human rights violations in our world today. These are largely unreported due to the silence, impunity, stigma and shame surrounding it. These acts of violence manifest in different forms like psychological, physical and sexual forms; intimate partner battering, psychological abuse, femicide, sexual harassment, forced sexual acts, street harassment, stalking, slavery, exploitation and female genital mutilation (WHO, 2018) Violence against women and girls is viewed "as any act of gender based violence that results in, or is likely to result in, physical, sexual, psychological harm or suffering to women, including threats of such acts, coercion or arbitrary deprivation of liberty, whether occurring in public or in private life" (UN, 1993a). Unfortunately, this continues to be an obstacle in achieving development, equality, peace as well as to the fulfillment of women and girl's rights (UN, 2019). No matter where in the world we live, we all have stories of how violence against women has affected our lives, someone we know or in our communities. A lot of research has been done on series of conflicts and human rights violation., especially among women, most of which centered on sexual violence, ignoring other aspects of violations against women in respect to media coverage and making victims' voices heard in search for justice and rehabilitation for survivors. Accordingly, the study aims at:

1. Critically reviewing the instances and coverage of violence against women during and after the sectarian crises in Plateau State.
2. Giving women a voice, to be able to speak out when faced with different forms of violence as well as helping those who are hurt to have a sense of belonging while justice is pursued.

3. Accessing the impact of sectarian crises and different forms of violence against women particularly in Plateau as well as media coverage of issues.

4. Highlighting experiences of women in sectarian crises in addition to sexual violence among others.

This study adopts the qualitative method, using relevant literature to unravel issues surrounding the press and violence against women during sectarian crises in the state, in addition to other extant reports on the conflicts which affect women.

\subsection{Conceptual Elucidation:}

\subsubsection{The Press :}

The press or media as would be used interchangeably in this work is conceived as all visual, auditory and audiovisual platforms for gathering, processing and transmission of information to large audiences. These platforms include print, electronic and social or new media. They are broadly classified into print which comprises of Newspaper, Magazine, and Periodicals as well as Electronic Media which includes Radio, Television and Social Media, the recent entrant (Dyikuk, 2017).

\subsubsection{Sectarian Crisis:}

In this study, sectarian crisis/crises encapsulates the various forms of conflicts in Plateau State and its environs which leads to the loss of lives and property as well as tensions, mutual reprisal acrimony, attacks and segregated living. We shall conceive sectarian crises as those socio-religious conflicts which are instantaneous in nature and create a guerilla-war-like situation where no one knows when the next enemy would hit or where he or she is coming from.

\subsection{Violence Against Women:}

Violence against women consists of a whole gamut of violation of the rights of women and girls which could be physical, psychological or spiritual. Although these can also be perpetrated by women, most of the violence meted out on women as the study would reveal are perpetrated by men. 


\subsection{Theoretical Framework:}

This study is guided by the Human Rights Consciousness Journalism Theoretical Framework which holds that press men and women and their organisations should be careful with the type of frames they select or produce (Dewan, 2018). The theory which inspires those in the journalistic profession, policymakers, and human rights advocates to improve the quality and consistency of their media profession argues that the press has the capacity to provide accurate, reliable, and timely information of issues which involve human rights (International Council on Human Rights Policy Journalism, 2002). The Human Rights Consciousness Journalism theory is concerned with how journalists and broadcasters go about investigation on human rights to their publics, how they see their task, how their job compares with other tasks, what pressures those who may be affected by their reportage put on them and what good reporting on human rights issues imply (International Council on Human Rights Policy Journalism, 2002). The theory further holds that the media might not tell us exactly what to think about concerning human rights but they direct us on what we should think of in two ways: First, as generators and sources of information, they gather, process and present most information about human rights abuses globally by classifying them into foreign or international news even as they perform the role of political and moral agent. This way, the press pays particular attention to stories by publishing decisive editorials which call for appropriate action.Second, as gatekeepers, the media are producers of information who have the moral concern that is inspired by defending human rights. By standing between human rights organisations and the wider public, the media focuses on a specific issue through agenda setting and surveillance.

\subsection{Literature Review And Discussion: \\ 3.1 Plateau State: Overview Of Sectarian Crises:}

Created out of the defunct Benue-Plateau State on February 3, 1976 by the Murtala Mohammed Regime, Plateau State was originally called "Gwosh" - as wrongly pronounced "Jos" by the Hausa settlers and traders. The state got its name from the Jos Plateau; a mountainous area in the north of the state known for captivating rock formations. Jos is the source of many rivers in northern Nigeria like the Kaduna, Gongola, Hadejia and Yobe rivers. The state has 17 Local Government Areas which include: Barkin Ladi, Bassa, Bokkos, Jos-East, Jos-North, Jos-South, Kanam, Kanke, Langtang North, Langtang South, Mangu, Mikang, Pankshin, Qua'an Pan, Riyom, Shendam and Wase (Alabi, 2017 \& Plateau State ICT Development Agency, 2019).

Known for Tin mining activities which began in 1902 under the British colonialists and still continues till date, the state has over 30 indigenous tribes: Afizere, Amo, Anaguta, Angas, Aten, Berom, Bogghom, Buji, Challa, Chip, Fier, Gashish, Goemai, Irigwe, Jarawa, Jukun, Kwagalak, Kwalla, Meryang, Miango, Miship, Montol, Mushere, Mupum, Mwaghavul, Ngas, Piapung, Pyem, Ron-Kulere, Rukuba, Taletc, Taroh, Youm. These indigenes people coexist peacefully with other tribes such as Hausa, Fulani, Igbo, Yoruba, Ijaw and Biniin to mention a few in the predominantly Christian state (Alabi, 2017).Located in north central Nigeria, Jos and the entire Plateau State which has the motto "the Home of Peace and Tourism" became a home of war (Asemah, \& Edegoh, 2012) due to escalating sectarian conflicts. Crises have occurred in Jos, Plateau in 2001, 2002, 2008 and 2010 which affected other parts of the state in rural areas outside the capital. Between 2001-2 and 2010, hundreds of people were killed in fields while farming or tending their cattle in villages. Scholars have indicated that the lack of organised religious and cultural traditions as well as total capture during the Jihad of Usman dan Fodio in 1804 (Dewan, 2019), made Jos, the Plateau State capital a sort of a hot cake. This made the city a central point for proselytisation and fertile ground for the establishment of new religious movements and ideas. For example, Muslim reformers like the Izala started in Jos in 1978. This group believes in Salafism which promotes a more scriptural or orthodox form of Islam that emphasizes the Sunna and denounces the heterodox practices of the Sufis (Higazi, 2011). In like manner, being the melting pot of the middle-belt that is blessed with good weather and rich stable food, Jos became an irresistible attraction for Christian missionaries who established their enterprise there. Although 
Muslims always had a strong presence in the city, it took an orientation towards Christianity. Within this time, the city maintained a cosmopolitan a culture of tolerance with friendly relations between adherents of the two religions. As time went on, the situation was undermined leading to religious competition, fundamentalism and assertiveness (Higazi, 2011).To mitigate the crises, various commissions of inquiry have been set up at the state and federal levels. From the Abisoye Presidential Panel of Inquiry to the Ajibola Commission which submitted its report on 27 October 2009, no permanent respite has been found as these judicial commissions of inquiry were not productive (Higazi, 2011). Apparently, this makes the situation in the state as sitting on the cake of a gun powder. The relative peace that is being enjoyed now can best be described as "disputed peace." This is because the calm may be breached at anytime.

\subsection{Possible Conflict-Drivers in the Plateau Crises:}

\subsubsection{Land Tussle between Indigenes (Farmers) and Settlers (Herders):}

The indigene (farmer) and settler (herder) narrative has been a major driver of the sectarian violence in Plateau State mostly between indigenous farmers, who are predominantly Christian and traders with livestock herders, mostly Hausa speaking and Muslims from other parts of northern Nigeria, because of land tussle (The New Humanitarian, 2004). It is becoming increasingly difficult for people to live in peace side by side each other in a country which has multiple ethnic groups because of the problem of citizenship and indigeneship. This is why the problem of ethnicity alongside considerable political interests is fingered as playing a central role in the conflicts (Higazi, 2011). Krause (2011) agrees that: "Tensions among the ethnic groups along the indigene-settler divide have long characterized inter-communal relations in Plateau State" (Krause, 2011, p.22).

\subsubsection{Fears Of Religious, Cultural And Political Domination:}

Many factors have contributed to the religious dimensions of the confrontation in Jos (Krause, 2011). There are indications that these feuds were also fuelled by religious suspicions which had been deepened by the introduction of strict Islamic
Shari'a Law in 12 Northern States from around (2000-2004). The Shari'a controversy was given a stamp of recognition when Nigeria returned to democratic rule in 1999 (Dewan, 2019). Most Christians saw the move as an attempt to achieve religious hegemony by Muslims (The New Humanitarian, 2004). Although the violence has mainly been along religious lines, between Muslims and Christians, another dimension is ethnicity. Various themes associated with the sectarian crisis are articulated on the basis of political exclusion particularly based on ethnicity and religion, on the part of Muslims and fears of religious and cultural domination by Plateau Christians (Higazi, 2011). "Both sides selectively point to historical records to justify their claim to the city of Jos, to indigene rights, and to political representation" (Krause, 2011, p.24). Dominant discourses like these on the conflicts further complicate the matter.

\subsubsection{Complicity In Handling Of The Crises:}

The inability of government in the state to bring the situation under control, with the permission of the federal parliament, President Bosanko removed the elected civilian Governor, Joshua Dairy and State House of Assembly accusing them of not doing enough to stop the bloodbath. When the President imposed an emergency rule on Plateau State, he appointed Chris Ali, a former Army General, as interim administrator of Plateau State (The New Humanitarian, 2004). Although successive administrations tired, escalating crises kept reoccurring.

\subsubsection{Retaliatory/Reprisal Attacks:}

While mutual suspicion held sway, there were a number of reprisal attacks on both sides leading to loss of lives and property. At various times, the fighting in Plateau spilled to other neighboring states where there were retaliatory attacks against Christians. In particular, scores of people were killed in religious clashes in Kano due to Jos crisis (The New Humanitarian, 2004).

\subsubsection{Hangover of Military Rule :}

As at 2004, it was observed that "more than 15 years of repressive military rule that had kept a tight lid on long-simmering grievances among the Nigeria's diverse peoples" (The New 
Humanitarian, 2004). The case in Plateau has been blamed on the creation of Jos North, a predominately Muslim area out of Jos South, a predominantly Christian area during the Military Junta of Ibrahim Babangida (Krause, 2011). It would be recalled that General Babangida's unilateral smuggling of Nigeria into Organisation of Islamic Conference (OIC) amidst public outcry across the country led to religious conflicts in northern parts of the country in places nieghbouring Plateau such as Kafanchan, Zangon Kataf and Balewa (Dewan, 2019). This ugly phenomenon has led to segregated settlements thus creating suspicion leading to further acrimony and crisis.

\subsection{Women As Victims Of Jos Crises: Statistical Indicators :}

According to The Committee of Rehabilitation and Reconciliation of Internally Displaced People, about 19,000 men and more than 17,000 women and 17,000 children were killed during 32 months of retaliatory violence between Christians and Muslims - 53,787 deaths in all (The New Humanitarian, 2004). In Plateau State, between January 2015 and September 2016, the effects of displacement and violence reverberated in the lives of women and girls (Relief Web Report, 2016). Women were affected in the conflicts in the following ways:

\subsection{Domestic Abuse:}

In the Plateau State, domestic abuse by male family members such as fathers, husbands, cousins and uncles as well as by trusted authority figures (Relief Web Report, 2016) were rife. Other forms of violence were non-sexual verbal abuse, abuse or humiliation by insulting, degrading, demeaning; compelling victims public or private barbaric acts like denying basic expenses for family survival as well as confinement which connotes isolating a person from friends or family, restricting movements, deprivation of liberty or obstruction/restriction of the right to free movement (Ugwu, Obioji \& Okechukwu, 2016).

\subsection{Rape And Sexual Assault:}

Domestic abuse, rape and sexual assault mostly males especially pastors and security forces accounted for most of the reported incidents of violence against women and girls in Plateau State
(Relief Web Report, 2016). Child sexual abuse, forced sodomy/anal rape, attempted forced sodomy, sexual exploitation, forced prostitution, sexual harassment and the use of violence as a weapon of war, use of torture, physical assault and human trafficking or slavery have been identified as examples of socio-psychology of gender based violence (Ugwu, Obioji, Okechukwu, 2016 \& Nanna \& Adejoh, 2018) against women.

\subsection{Psychological, Spiritual And Emotional Abuse:}

Violence against women has direct and indirect psychological impact on victims. Some of the direct consequences include anxiety, fear, mistrust, lack of concentration, posttraumatic stress disorder, depression, suicide, the indirect consequences are psychosomatic illnesses, withdrawal, alcohol and drug abuse (Ugwu, Obioji \& Okechuku, 2016). Dyikuk and Dongvel (2019) aver that violent actors employ sexual violence against women so as to inflict both physical and psychological pain on their victims. It is critical to understand the effects of violence on the lives of women and girls so as to better inform appropriate prevention and response efforts (Relief Web Report, 2016).

\subsection{Socio-Economic Violence:}

Women undergo socio-economic deprivations and violence such as discrimination or denial of opportunities and services, social exclusion/ostracism based on sexual orientation and obstructive legislative practice like prevention of the exercise of civil, social, economic, cultural and political rights by women (Ugwu, Obioji \& Okechukwu, 2016).Some of the few instances of the crises which took its toll on women include.

- October 2004: On 8 October 2004, IRIN, a media project of the UN Office for the Coordination of Humanitarian Affairs reported that more than 17,000 women were killed during 32 months of retaliatory violence between Christians and Muslims (Higazi, 2011).

- November 2008: The memoranda of the "Jos North Muslim Ummah" indicated that a total of 39 women mostly of Hausa/Fulani Muslim 
extraction killed on 28-29 November 2008 (Higazi, 2011).

- January 2010: The worst massacre took place at Kuru Karama 19 January 2010 where 36 women were killed (Human Rights Watch, $2013 b)$.

- March 2010: On 7 March 2010 a massive attack was launched on the village of Dogo Nahauwa, an old mining settlement in Shen village area of Jos South LGA were over 34 women were murdered in cold blood (Human Rights Watch, 2013b).

\subsection{Effects Of Gender-Based Violence: Evidence From Literature:}

The effects of these acts of violence against women are huge. In a recent study, Dyikuk and Kanu (2018) identified physical, psychological and psycho-spiritual effects of violence against women. We shall highlight these as follows:

\subsection{Physical Effects:}

Some of the effects of the crises reveal that many women lost their husbands leaving them to cater for their children alone. The situation is worse because many small businesses that were done by women in Jos and Bukuru metropolis were destroyed during repeated acts of violence (Krause, 2011). Also, "because of the devastating effects of violence, most women who are abused end up with physical bruises or Vesico-Vaginal Fistula (VVF). Others are unable to give birth again in their entire lives because of the physical torture, beating and forced labour. Some have had to lose hands and limps in an attempt to either escape or serve their abductor's needs" (Dyikuk \& Kanu, 2018).

5.2 Psychological Effects: Acts of violence reduce the self-esteem and humanity of its victims. It affects them psychologically. In the end, they either become paranoid or are sacred of any future sexual relationship with men believing that all men are abusers.

5.3. Psycho-Spiritual Effects: Victims of violence are often demoralized. They tend to think that other people see them as bad people. This creates a sense of vulnerability in them leading to self-pity and regrets. That way, they could lose their moral and spiritual balance and even attempt suicide (Dyikuk \& Kanu, 2018).

\subsection{Jos Sectarian Crises: The Role of The Press:}

In what was once considered as a media desert, there are various newspapers, radio and television stations across Plateau State. For instance, the state is home to State Government owned Radio/Television Stations like, Plateau Radio Television Corporation PRTVC, Nigeria Television Authority and News Agency of Nigeria (NAN) owned by the Federal Government. These are also Private Radio/Television stations like Africa Independent Television (AIT), Ray Power Radio Station, Silver Bird Communication with both Television and Radio Broadcasting in Jos (Mangud, 2018). The list of radio FM stations in the state include: 90.5 - Peace FM, owned by the Plateau State Government (listed earlier), 100.5 - Ray Power FM, owned by DAAR Communications, 93.7 - Rhythm FM, owned by Silver Bird Communications, 101.5 Highland FM owned by the Federal Radio Corporation of Nigeria (FRCN), 96.1 - Ice FM, owned by the University of Jos, 98.9 - Rock FM, owned by the Plateau State Polytechnic; others include, 93.3- Unity FM, owned by Ibrahim Dasuki Nakande, ex-senator from Plateau North, 104.3 - Tin City FM, 101.9 - Jay FM, owned by the Jonah Jang Family and 103.9 - KT FM. This is indication that the media landscape in Plateau is growing at an alarming rate (Nwabueze , 2019).We shall now consider the positive and negative roles of the press in the state:

\subsection{Positive View Of Reporting The Plateau Crises}

6.1.1 Dowsing Escalating Conflicts

There are also indications that in many cases, media reports in Plateau have escalated dowsing conflicts already having headways to peaceful agreements and developments (Mangud, 2018). This is attributed to the hard work of journalists in the state.

\subsubsection{Creating And Sustaining Political Pluralism:}

Various newspapers, radio and television stations $n$ the state "have a very distinct perception of their own role in the process of creating and 
sustaining an element of political pluralism"(Mangud, 2018,p.37). For example, "The Nigerian Television Authority, Jos Network Centre and the Plateau State Radio and Television Corporation, as the major electronic media that have been in the fore-front for the promotion of peaceful co-existence among the different ethnic groups in Plateau State. Radio was identified as the major medium through which the discussants heard about the message of peaceful co-existence" (Asemah, \& Edegoh, 2012,p.122).

\subsection{Negative Role Of The Press İn Jos Conflicts:}

Notwithstanding the positive view of the role of press in the sectarian crises, we shall group the possible factors responsible for the failure of the media to put a permanent end to violence against women on the Plateau into categories:

\subsubsection{Ethnic And Religious Bias:}

Scholars have emphasized that: "The media become polarised in terms of reportage during crisis in Plateau State - the journalist often reports to favour his religion, ethnicity (Asemah, \& Edegoh, 2012,p.122). Unethical practices in reporting conflicts are religion, ethnicity, ownership interest and unprofessionalism (Galadima cited in Pate (2002). In the north, media reports are not divorced from the vagaries of ethnicity and religion. And because the media are owned by people with diverse interests, when there are conflicts, those ethnic, religious and political interest manifest (Yushau, 2015). On many occasions, some of the information the media passes for public consumption in the state cannot be trusted because of the biased nature of such reports (Mangud, 2018).

6.2.2 Lack Of Fair Reportage:Ethnicity and religion are identified as major cause of press-bias in Nigeria (Olayiwola, 1991). This position played out in Plateau where local journalists were said to have struggled with the tendency to report without bias. For instance, while some Muslims complained of bias in some local newspaper accounts, a Christians claimed that their deaths were under-reported (Krause, 2011). In most cases, "The reporter who is ready to exhibit professionalism may think less of the negative effect of his report on the society. So escalation of conflicts is not even his/her mind (Mangud, 2018, p. 37). In another study, discussants agreed that: "The media have not been objective and thus, they have not been fair..." (Asemah, \& Edegoh, 2012,p.122).

\subsubsection{Failure of International Media:}

Both Christians and Muslims have fiercely criticized local and international news coverage of the Jos crisis. For example, while some Christians decried the failure of the international media to understand to what extent Christians have been victimized, Muslims complained of bias in some local newspaper accounts (Krause, 2011).

\subsubsection{False Reportage:}

On the destructive role of the media in the conflicta, it has been documented that the media in Plateau state has been accused of dishonesty in its reportage and falsely disseminating information in various forms which has worsened the public perception about the press (Mangud, 2018).

\subsubsection{Challenges Facing Journalists:}

Journalist in the state are faced with challenges such as lack of insurance cover, intimidation of journalists, poor remuneration of media workers and lack of thorough investigative reporting skills. These problems are possible factors responsible for the inability of the press across the country to curb insurgencies or sectarian crises (Dyikuk \& Dongvel, 2019).

\subsubsection{Other Multiple Challenges:}

It has been observed that mass media organisations face various challenges such lack of professional training or knowledge of the environment, issues around editorial policy, the problem of ownership of media organization, attempt by comedia practitioners to out shine one another, threat of new media, sour relationship between government and media institutions and immediate community influence their coverage of conflict on the Plateau (Mangud, 2018).

\subsection{Conclusion and Recommendations: 7.1 Conclusion:}


The study established that the press is a critical stakeholder in reporting violence against women on the Plateau. We saw that women are the worst hit during sectarian crises as their husbands are often killed and they are left to raise orphaned children. In the light of the Human Rights Consciousness Journalism Theoretical Framework, this paper canvases for conscious and thorough reportage of all forms of violence against women and girls. As responsible stakeholders, media organisations have the obligation to cover and publish women issues in an objective manner. The frames they select or produce should be motivated in line with the surveillance role of the press as the watchdog of society.The study recommended women education, recruiting more women journalists, thorough reportage of women-related issues, proactive measures by female-journalists, training and support for journalists, upholding media principles, compliance with national policy on gender and domesticating violence against women protocols as possible panacea to the lingering sectarian crises which adversely affects women in Plateau State. In a society where more women study journalism but their male counterparts are working all over print and electronic media corporations, women should be given their rightful place in the media industry. This might likely reduce the menacing effect of gender-based violence and exonerate the press from complicity in reporting women in conflict on the Plateau and beyond.

\subsection{Recommendations:}

\subsubsection{Women Education/Recruiting More} Women Journalists:

In line with the aspirations of the Sustainable Development Goals (SDGs), there is need for governments everywhere and stakeholders to drum support for the education of the girl child and inclusion of women in every sector of human endeavour (Dyikuk \& Kanu, 2018). While advocating for recruitment of more women journalists across the country, it is expedient to debut insurance covers for those reporting women (Dyikuk \& Kanu, 2018).

\subsubsection{Thorough Reportage Of Women-Related Issues:}

The media and policy makers should ensure that survivors of violence against women are heard and the world is a safe place for women and girls both during peace and crises. This can be achieved through amplifying the voices of women in the state as well as stimulating dialogue to ensure that the perpetrators are brought to book. To this end, gender mainstreaming is crucial to minimizing gender-based violence on the Plateau (Ugwu, Obioji \& Okechukwu, 2016). By same token, "The onus lies on operators of media firms to ensure that only stories which have been verified are published" (Dyikuk, 2017,p. 041).

\subsubsection{Proactive Measures by Female- Journalists:}

The press should try to uphold its ethical standards by not putting survivors in danger and reinforcing harmful stereotypes. It should also shift focus away from perpetrators by not revealing sensitive information that can jeopardize the safety of victims. Since experts have established that women can play a leading role in conflict resolution, it is expedient to give them a chance so as to contribute meaningfully in checking genderbased violence (Ugwu, Obioji \& Okechukwu, 2016).

\subsubsection{Training and Support for Journalists:}

Because the training and retraining of journalists by their paymasters hardly gets the desired attention (Dewan, 2019), there is an urgent need to support journalists with training on contemporary style of journalism with particular reference to violence against women, its causes, experiences in communities throughout the state and ethics of reporting. These training workshops for journalists in the light of communal conflicts are catalysts for curbing sensationalist reporting (Kraus, 2011). International media organisations like the British Broadcasting Corporation (BBC), Cable News Network (CNN), Associated Press (AP), Reuters and bodies like the National Association of Women Journalists (NAWOJ) should organize periodic workshops for female journalists from the global south.

\subsubsection{Upholding Media Principles:}

Relevant stakeholders in the media industry especially the Nigeria Union of Journalists (NUJ), The Nigeria Press Council (NPC) and other such regulating bodies should ensure that journalists are 
trained on the basic principles and ethics of reporting cases of violence against women. In view of Human Rights Consciousness Journalism, journalists and their news organisations should be sensitive with the type of frames they select or produce (Dewan, 2018).

\subsubsection{Compliance With National Policy On Gender:}

Since Nigeria has promulgated the National Policy on Gender Matters, it is necessary to follow the demands of that promulgation to the latter as this would help in incorporating gender issues into other national policies and programmes in keeping with the $35 \%$ benchmark for women participation in governance (Ugwu, Obioji, Okechukwu, 2016 \& Kelly, 2019). Indeed, this would help to eliminate gender-based stereotypes towards fostering a culture of fairness and peace (Ugwu, Obioji \& Okechukwu, 2016). Perhaps this in addition to a thorough international investigation by the International Criminal Court (ICC) (Higazi, 2011) on the violence against women would help.

\subsubsection{Domesticating Violence Against Women Protocols:}

Previous treaties and protocols by the United Nations as well as those of regional/sub-regional organizations and international law have addressed violence against women. Therefore, it is incumbent on the media to hold member states accountable towards domesticating these laws through legislation (Ugwu, Obioji \& Okechukwu, 2016) to give women their rightful place and dignity in society.

\section{References}

1. Alabi, T (2017). A brief history of Plateau State. www.informationng.com/2017/03/briefhistory-plateau-state.html Accessed 4/26/2020.

2. Alawemo, O. \& Muterera, J. (2010). The Impact of armed conflict on women: Perspectives from Nigerian women. OIDA International Journal of Sustainable Development, Vol. 2 No. 5 [81-86].

3. Asemah, E.S \& Edegoh, L. O (2012). Mass media agenda and conflict resolution in Jos,
Plateau State, Nigeria. An International Journal of Arts and Humanities Bahir Dar, Ethiopia Vol. 1 (4), [112-129].

4. Campbell, J (2019). The numbers behind sectarian violence in Nigeria. www.cfr.org/blog/update wWw.opentextbc.ca/women. Accessed $\underline{18 / 3 / 2020 .}$

5. Dewan, A.D (2018). The influence of ethnicity in newspaper coverage of the Plateau State conflict in north-central Nigeria (20102012). (PhD), University of Salford, Manchester, United Kingdom.

6. Dewan, A.D (2019). Reflection on media, ethnicity and religion: Challenges of reporting conflicts in Nigeria. Jos Journal of Media and Communication Studies (JJMCS), 2(4) [252269].

7. Dyikuk J.J \& Kanu I.A. (2018). Boko Haram's violence against women: What can the media do? In Ndubisi E.J \& Kanu I.A (Eds.). Gender equality and power relations in Africa: Insights from religion and sociocultural perspectives. [9-31]. Mauritius: LAP Lambert Academic Publishing.

8. Dyikuk, J.J \& Dongvel, D.M (2019). The role of the media in investigating the entrepreneurs of Boko Haram insurgency. Jos Journal of Media and Communication Studies (JJMCS), 2(4) [307-322].

9. Dyikuk, J.J (2017). Towards improving governance in Nigeria through the media. International Journal of Journalism and Mass Communication Vol. 3(1), [029-042].

10. Galadima, J. D. (2002). "Basics of conflicting reporting," in Pate, A. U. (Ed). Introduction to conflict reporting in Nigeria. Lagos: Frankard publishers.

11. Higazi, A (2011). The Jos crisis: A recurrent Nigerian tragedy. Discussion paper. No. 2. Friedrich-Ebert-Stiftung, Abuja, Nigeria. 
12. Human Rights Watch (2013b). "Leave Everything to God": Accountability for intercommunal violence in Plateau and Kaduna States, Nigeria. [49-81]. www.hrw.org/report/2013/12/12/leaveeverything-god/accountability-intercommunal-violence-plateau-and-kaduna. Accessed 4/26/2020.

13. International Council on Human Rights Policy Journalism, (2002), Media and the challenge of Human Rights reporting. Versoix, Switzerland.

14. Kelly, L. (2019). Barriers and enablers for women's participation in governance in Nigeria. K4D Helpdesk Report. Brighton, UK: Institute of Development Studies.

15. Krause, J (2011). Working paper: a deadly cycle: ethno-religious conflict in Jos, Plateau state, Nigeria. Switzerland: Geneva Declaration Secretariat.

16. Mangud, E.M (2018). The role of media in conflict management: A case study of Jos North Local Government Area of Plateau State Nigeria. B.SC Mass Communication Thesis. Department of Mass Communication, Faculty of Social Science. National Open University of Nigeria Jos Study Centre.

17. Nanna, L \& Adejoh S (2018). Terrorism and conflict-related sexual violence in Africa: Northeastern Nigeria in Focus. Covenant University Journal of Politics \& International Affairs. Vol. 6 No. 1, [76-88].

18. Nwabueze , C (2019). List of radio stations in Jos. https://massmediang.com/list-of-radiostations-in-jos/. Accessed 4/26/2020.

19. Olayiwola, R.O (1991). Political communication: Press and politics inNigeria's Second Republic. Africa Media Review, 5(2), [31-45].

20. Plateau State ICT Development Agency (2019). Local Government Area. www.plateaustate.gov.ng/government/lgas. Accessed 4/26/2020.
21. Relief Web Report (2016). Impacts of Conflict, violence on women and girls in Nigeria's,Plateau,State.https://reliefweb.int/repo $\mathrm{rt} /$ nigeria/impacts-conflict-violence-womenand-girls-nigerias-plateau-state.Accessed 4/24/2020.

22. The New Humanitarian (2004).Plateau state violence claimed 53,000 lives report.www.thenewhumanitarian.org/news/2004 /10/08/plateau-state-violence-claimed-53000lives-report.Accessed 4/24/2020.

23. Ugwu, C.C; Obioji, J. E \& Okechukwu, I (2016). Gender -based violence in Nigeria: The trends and ways of forward. Science Arena Publications Specialty Journal of Politics and Law. Vol. 1 (1) [99-115].

24. UNFPA Arab States Regional Humanitarian Response HUB (2020). Reporting on GenderBased Violence in the Syria Crisis: A Journalist's Handbook. UNFPA(2014) www.unfpa.org/resource. Accessed 18/3/2020.

25. United Nations (2019). International Day for the elimination of violence against women. www.un.org/en/event/end-voilence-now. Accessed 18/3/2020.

26. World Health Organization (2018). Strengthening the health response in times of crisis. www.who.int/news-room/featurestories/detail/voilence-against-women.Accessed 18/3/2020.

27. Yusha'u, M.J (2015). Regionalism and ethnicity in the Nigerian press: An analysis of the coverage of Boko Haram and the Niger Delta conflict in the Guardian and Daily Trust. In W. Mano (Ed.), Racism, Ethnicity and the Media in Africa: Mediating Conflict in the Twenty-First Century [137-156]. London: I.B Tauris. 